\title{
Dietary fat affects lipids and anti-cardiolipin antibody levels in autoimmune-prone NZB/W F1 mice
}

\author{
BY BI-FONG LIN ${ }^{1 *}$, SU-JEN JENG ${ }^{1}$, BOR-LUEN CHIANG ${ }^{2}$ AND CHAO-CHI HUANG ${ }^{1}$ \\ 'Laboratory of Nutritional Chemistry, Department of Agricultural Chemistry, College of Agriculture, and \\ ${ }^{2}$ Graduate Institute of Clinical Medicine, College of Medicine, National Taiwan University, Taipei, \\ Taiwan 10764, Republic of China
}

(Received 10 April 1996 - Revised 22 July 1996 - Accepted 25 July 1996)

\begin{abstract}
Studies in autoimmune-prone NZB/W F1 mice have demonstrated that the amount of dietary fat can affect autoantibody production and the disease course of autoimmune diseases. Anti-cardiolipin antibodies have been found to play a major role in thrombus formation and the increase of abortion rate in both human lupus patients and murine lupus. The present study investigated further the effect of dietary fat on lipid and anti-cardiolipin antibody production in autoimmune-prone mice. Two groups of NZB/W F1 mice were fed on diets containing $200 \mathrm{~g}$ dietary fat $/ \mathrm{kg}$ and $50 \mathrm{~g}$ dietary fat/kg respectively, the fat being composed of equal amounts of lard and soyabean oil. Serum levels of lipids, immunoglobulin (Ig) anti-single stranded DNA and anti-cardiolipin antibodies were followed regularly every month and mice were killed for in vitro experiments after 5 months on the experimental diets. The results showed that serum triacylglycerol concentration was lower in mice fed on the high-fat diet than in those fed on $50 \mathrm{~g}$ fat $/ \mathrm{kg}$. There was no significant difference in hepatic lipid contents; however, the fatty acid contents were different between these two groups. Hepatic linoleic acid (18:2n-6) and arachidonic acid (20:4n-6) concentrations were higher in mice fed on the high-fat diet. There were no significant differences in serum IgM concentrations or IgM anti-cardiolipin antibody levels between these two groups. However, IgG anti-cardiolipin antibody levels were higher in mice fed on the high-fat diet at the age of 3-4 months. Total serum IgG concentration was noted to be higher, but in contrast, serum IgA was lower, in the high-dietary-fat group. These findings suggest that high dietary fat may affect lipid metabolism and autoantibody levels in autoimmune diseases.
\end{abstract}

Systemic lupus erythematosus: Autoimmunity: Cardiolipin

Murine lupus models such as NZB $\times$ NZW F1 $\left(\right.$ NZB/W F1), NZB.H-2 ${ }^{\text {bm12 }}$, NZB $\times$ SWR F1 (SNF1), MRL.lpr/pr and BXSB mice develop a wide spectrum of autoantibodies against erythrocytes, DNA, ribonucleoproteins and phospholipids (Theofilopoulos et al. 1989). Among them, the anti-cardiolipin antibody has been closely related to venous and arterial thrombosis, thrombocytopenia, neurological diseases and recurrent fetal loss (Lockshin et al. 1985; McNeil et al. 1991) Cardiolipin is a mitochondrial dianionic and tetra-acylated phospholipid, which may contain up to $85 \mathrm{~g}$ linoleate $/ 100 \mathrm{~g}$ in mammals (Berger et al. 1992). Anti-cardiolipin antibody is a heterogeneous group of autoantibodies which may cross-react with negatively charged phospholipids, such as phosphatidylserine and phosphatidylinositol (Rauch et al. 1984; Eilat et al. 1986; Haeeis et al. 1987).

A low-fat and low-energy diet can reduce anti-DNA antibodies and prolong life span in autoimmune NZB/W F1 mice (Fernandes et al. 1976; Kubo et al. 1984; Gajjar et al. 1987). A previous study showed that mice fed on a high-fat diet, which contained equal amounts

*For reprints. 
of lard and soyabean oil, developed more severe disease and had a shortened life span (Lin et al. 1996). However, the metabolism of dietary fat in NZB/W F1 mice still needs to be investigated. It has been reported that phospholipids, especially cardiolipin, can compete with the DNA binding activity of monoclonal anti-DNA antibodies (Lafer et al. 1981). Polyspecific anti-DNA antibodies in sera from patients with systemic lupus erythematosus (SLE) have been demonstrated to cross-react with cardiolipin (Koike et al. 1982, 1984). However, the role of anti-cardiolipin antibodies in the pathogenesis of SLE has not been clearly elucidated. Two studies showed that an increase in vascular diseases was found only in lupus patients with increased serum triacylglycerol levels, suggesting that serum triacylglycerol level is closely related to production of anti-cardiolipin antibodies and subsequent vascular diseases (Hashimoto et al. 1992; MacGregor et al. 1992). A high-fat diet might have a critical effect on the serum levels of triacylglycerols, cholesterol and phospholipids, and subsequent anti-phospholipid antibody production which may result in further pathological damage in SLE patients.

No study concerning the effect of fat nutrition on anti-cardiolipin antibody production in autoimmune-prone NZB/W F1 mice has been documented. The present study investigates further the effect of high dietary fat on serum levels of triacylglycerol, cholesterol, phospholipid and immune responses, including anti-cardiolipin and antisingle-stranded DNA (anti-ssDNA) antibody levels, serum total immunoglobulin (Ig)G, IgM and IgA concentrations and mitogen responses.

\section{MATERIALS AND METHODS}

\section{Experimental animals}

Four-week-old female NZB/W F1 mice were purchased from Charles River Japan (Tokyo, Japan). BALB/c (Mus musculus) mice were obtained from the Animal Centre, College of Medicine, National Taiwan University. The mice were housed and fed individually in an animal room (12 h light and $12 \mathrm{~h}$ dark) with constant temperature $\left(25 \pm 2^{\circ}\right)$ and humidity. Each group consisted of sixteen mice. Each mouse was fed on the experimental diet starting from 1 month old, and six to eight mice were killed for in vitro experiments after 5 months' feeding. The rest of the mice were maintained for proteinuria and lifespan followup to confirm the pathogenic changes of these mice. Animal care and handling conformed to the NIH Guide for the Care and Use of Laboratory Animals (National Research Council, 1985).

\section{Diet}

The compositions of the diets and sources of ingredients have been described previously (Lin et al. 1996). The experimental diets contained (g/kg): casein 200, DL-methionine 3, cellulose 50 , choline bitartrate 2 , vitamin mixture 10 , mineral mixture 35 . The high-fat group's feed contained $200 \mathrm{~g}$ fat $/ \mathrm{kg}$ and the low-fat group's feed contained $50 \mathrm{~g}$ fat $/ \mathrm{kg}$. The fat was composed of equal amounts of lard and soyabean oil to mimic ordinary human dietary fat consumption. The difference in energy content was compensated for by carbohydrates. The high-fat diet contained $250 \mathrm{~g}$ maize starch $/ \mathrm{kg}$ and $250 \mathrm{~g}$ sucrose $/ \mathrm{kg}$. The low-fat diet contained $325 \mathrm{~g}$ maize starch $/ \mathrm{kg}$ and $325 \mathrm{~g}$ sucrose $/ \mathrm{kg}$. The mice were given free access to feed, weighed twice weekly, and feed consumption was measured every 2-3 d. The fatty acid pattern of the dietary fat is summarized in Table 1. 
Table 1. The fatty acid contents of the low-fat diet and the high-fat diet, and the fatty acid pattern in the dietary fat composed of equal amounts of lard and soyabean oil

\begin{tabular}{lccc}
\hline & $\begin{array}{c}\text { Composition of fat } \\
\text { F(g/100 g total fatty acids) }\end{array}$ & \multicolumn{2}{c}{ Content in diet (g/kg diet) } \\
\cline { 3 - 4 } & & $50 \mathrm{~g} \mathrm{fat} / \mathrm{kg}$ & $200 \mathrm{~g}$ fat $/ \mathrm{kg}$ \\
\hline $14: 0$ & 0.75 & 0.375 & 1.5 \\
$16: 0$ & 17.90 & 8.95 & 35.8 \\
$16: 1 n-9$ & 1.30 & 1.65 & 6.6 \\
$18: 0$ & 8.00 & 4.0 & 16 \\
$18: 1 n-9$ & 33.05 & 16.53 & 66.1 \\
$18: 2 n-6$ & 33.75 & 16.88 & 67.5 \\
$18: 3 n-3$ & 3.90 & 1.95 & 7.8 \\
$20: 4 n-6$ & ND & ND & ND \\
\hline
\end{tabular}

ND, not detectable.

\section{Serum and liver triacylglycerol, cholesterol and phospholipid levels}

Mice were bled retro-orbitally every month and serum was collected for determination of serum triacylglycerol, cholesterol, phospholipid, anti-cardiolipin and anti-ssDNA antibodies, and total serum immunoglobulins. Serum triacylglycerol, cholesterol and phospholipid concentrations were measured by colorimetric procedures. The triacylglycerols were determined after enzymic hydrolysis with lipase (EC 3.1.1.3), glycerol kinase ( $E C$ 2.7.1.30) and glycerol-3-phosphate oxidase (EC 1.1.99.5) to produce $\mathrm{H}_{2} \mathrm{O}_{2}$ (Fossati \& Prencipe, 1982). Serum cholesterol was determined as free cholesterol, and as cholesterol released from its esters after cholesterol esterase (EC 3.1.1.13) hydrolysis, and oxidized by cholesterol oxidase (EC 1.1.3.6) to produce $\mathrm{H}_{2} \mathrm{O}_{2}$ (Richmond, 1973; Carlson \& Goldfarb, 1979). The phospholipid was hydrolysed by phospholipase $\mathrm{D}(E C$ 3.1.4.4) and oxidized by choline oxidase $\left(E C\right.$ 1.1.3.17) to produce $\mathrm{H}_{2} \mathrm{O}_{2}$. The indicator, quinoneimine, of these assays is formed from $\mathrm{H}_{2} \mathrm{O}_{2}$, 4-aminoantipyrine, phenol or 4-chlorophenol, in the presence of peroxidase (EC 1.11.1.7; Takeyama et al. 1977), and was read at $500 \mathrm{~nm}$ using a spectrophotometer (U-3400 Hitachi, Tokyo, Japan). The triacylglycerol and cholesterol assay kits were purchased from Randox Laboratories Ltd (Antrim, N. Ireland). The phospholipid assay kits were purchased from Kyokuto Pharmaceutical Industrial Co., Ltd (Tokyo, Japan).

\section{Serum and liver fatty acid composition analysis}

To investigate further the effect of fat intake on fatty acid composition, serum and liver fatty acid compositions were analysed. Six to eight mice of each group were killed by $\mathrm{CO}_{2}$ asphyxiation after 5 months of consuming the experimental diets. Livers were excised, weighed and a portion, of approximately $0.5 \mathrm{~g}$, was extracted with chloroform-methanol $(2: 1, \mathrm{v} / \mathrm{v})$ and prepared for further analysis of triacylglycerols, cholesterol, phospholipid and fatty acid composition according to the method described by Folch et al. (1957). Hepatic triacylglycerol, cholesterol, phospholipid and total lipids were measured by colorimetric methods with commercial assay kits as described earlier. The total lipid assay kits were purchased from Randox Laboratories Ltd. The fatty acid compositions were analysed according to the method of Lee et al. (1990). 


\section{Determination of anti-cardiolipin antibodies}

Serum anti-cardiolipin antibody levels were determined using ELISA (Haeeis et al. 1987; Rupin et al. 1991). Briefly, ELISA plates were pre-coated with $150 \mu$ protamine sulphate/ well and incubated at room temperature for $2 \mathrm{~h}$. Then, the plates were washed three times with phosphate-buffered saline (PBS) and coated with $50 \mu 1$ bovine heart cardiolipin/well (Sigma Chemical Co., St. Louis, MO, USA) in absolute ethanol at a concentration of $100 \mu \mathrm{g} / \mathrm{ml}$. The control well (cardiolipin-free) was treated with $50 \mu \mathrm{l}$ absolute ethanol as a non-specific binding background. The plates were air-dried at room temperature and washed once with PBS. Subsequently, the plates were blocked with $200 \mu \mathrm{l}$ adult bovine serum (100 g/l; ABS)/well) and incubated at $37^{\circ}$ for $1 \mathrm{~h}$. After three washes with PBS, sera to be determined were diluted $1: 50$ or $1: 100$ in ABS $(100 \mathrm{~g} / 1)$ and $50 \mu \mathrm{l}$ was added to the appropriate wells. After $2 \mathrm{~h}$ incubation at room temperature, plates were then washed nine times with PBS and peroxidase-conjugated goat anti-mouse IgG or IgM ( $\gamma$ - and $\mu$-chain specific, Jackson Inc., West Grove, PA, USA) secondary antibodies were added and incubated at room temperature for $1 \mathrm{~h}$. After nine washes with PBS, adequate substrate was added for colour development and the reaction was stopped with $50 \mathrm{~g} / 1$ SDS. Absorbance was determined at $415 \mathrm{~nm}$ (Microplate, Bio-Tek Instrument, Inc., Winooski, VT, USA). Sera of SLE patients were used as positive controls; procedures were the same except for secondary antibodies. All the values were assayed in triplicate and obtained by subtracting the non-specific binding of each sample.

\section{Determination of anti-single stranded DNA antibodies}

Levels of anti-ssDNA were quantified by ELISA on Immunolon I (Nunc Inc., Roskilde, Denmark). For the assay of anti-ssDNA antibodies, plates were initially coated with $100 \mu \mathrm{l}$ methylated bovine serum albumin $(10 \mu \mathrm{g} / \mathrm{ml}) /$ well. Stock calf thymus DNA $(500 \mu \mathrm{l} / \mathrm{ml}$ in PBS) was denatured by boiling for $15 \mathrm{~min}$, then incubated on ice for $5 \mathrm{~min}$ with agitation. The denatured stock was diluted to $2.5 \mu \mathrm{g} / \mathrm{ml}$ with PBS and added to the plates at $100 \mu \mathrm{l} /$ well. The subsequent procedure was the same as that for the determination of anti-double stranded DNA antibodies described previously (Lin et al. 1996).

\section{Serum immunoglobulin levels}

Serum IgG, IgM and IgA levels were quantified by radial immunodiffusion, and the assays were validated with standard mouse IgG, IgM and IgA. The assay kits were purchased from Serotec Ltd (Oxford, Oxon).

\section{Mitogen responses}

Single spleen cells were plated in ninety-six-well round-bottomed plates with a concentration of $1 \times 10^{6}$ cells/ml in RPMI 1640 medium supplemented with $100 \mathrm{ml}$ fetal calf serum/1, $4 \mathrm{mM}$-L-glutamine, $25 \mathrm{mM}$-HEPES, $5 \times 10^{-5} \mathrm{M}$-2-mercaptoethanol, $100 \mathrm{U}$ penicillin $/ \mathrm{ml}, 100 \mu \mathrm{g}$ streptomycin $/ \mathrm{ml}$ and $0.25 \mathrm{mg}$ amphotericin $/ \mathrm{ml}$ in the absence or presence of mitogen. The optimal concentrations of the mitogens for this study were pretested and 5 or $25 \mu \mathrm{g} / \mathrm{ml}$ lipopolysaccharide (LPS; Sigma), 5 or $10 \mu \mathrm{g} / \mathrm{ml}$ concanavalin A (Con A; Sigma) were used in triplicate for the present study. The cells were incubated at $37^{\circ}$ with $5 \% \mathrm{CO}_{2}$ for $72 \mathrm{~h}$. At $16 \mathrm{~h}$ before harvest, $37 \mathrm{KBq}\left[{ }^{3} \mathrm{H}\right]$ thymidine was added to each well. The cells were harvested and radioactivity was measured with a $\beta$-counter 
(Beckman LS 5000 CE; Beckman, Los Angeles, CA, USA). The data were expressed as stimulation index.

\section{Statistical analysis}

The significance of difference between groups was analysed statistically by the two-sided non-paired Student's $t$ test of the SAS program system (SAS/STAT, version 6, 1990; SAS Institute Inc., Cary, NC, USA) throughout this study. Differences were considered significant at $P<0.05$.

\section{RESULTS}

\section{Feed intake and growth}

There was no significant difference in feed intake and body weight between mice fed on diets containing 50 and $200 \mathrm{~g}$ fat $/ \mathrm{kg}$ before the onset of disease at 7-8 months old. The average daily feed intakes of mice were 3.7 (SD 0.4) $\mathrm{g}$ for the low-fat diet group and 3.2 (SD 0.5 ) $\mathrm{g}$ for the high-fat diet group. The daily energy intakes were similar between these two groups (60.5 (SD 6.3) kJ for the low-fat diet group and 61.6 (SD 9.9) kJ for the high-fat diet group). The body weights of mice were 46.7 (SD 3.8) $\mathrm{g}$ for the low-fat diet group and 46.4 (SD 3.6) $\mathrm{g}$ for the high-fat diet group at 6 months old. However, the average feed intake and body weight decreased in mice of the high-fat group starting from 8 months old as described previously (Lin et al. 1996). In addition, the life span of mice fed on the highfat diet (285 (SD 60) d) was found to be shorter than that of mice fed on the low-fat diet (389 (SD 97) d, $P=0.0439$ ).

\section{Serum triacylglycerol, cholesterol and phospholipid concentrations}

The serum lipid profiles of mice fed on diets containing different amounts of dietary fat are shown in Fig. 1. Serum triacylglycerol levels were lower in mice fed on $200 \mathrm{~g}$ fat $/ \mathrm{kg}$ compared with those in mice fed on $50 \mathrm{~g}$ fat $/ \mathrm{kg}$ diet $(P<0.05, P=0.0574$ at 4 months, Fig. 1(a)). In contrast, cholesterol and phospholipid levels between mice fed with different amounts of dietary fat were very similar (Fig. 1(b), 1(c)). However, it should still be pointed out that both cholesterol and phospholipid levels of mice fed on the high-fat diet were lower than those of the low-fat diet group at 6-7 months of age.

To compare with the lipid profile in female NZB/W F1 mice, serum lipid contents of three BALB/c and three male NZB/W F1 mice fed on laboratory chow diet at 3 months of age were measured. The serum triacylglycerol concentrations of BALB/c mice and NZB/W

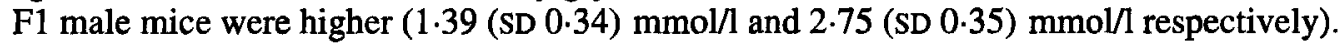
In contrast, the serum cholesterol concentrations of $B A L B / c$ mice and male NZB/W F1 mice were lower $(2.04$ (SD 0.34) $\mathrm{mmol} / 1$ and 4.11 (SD 0.78) $\mathrm{mmol} / 1$ respectively). The serum phospholipid concentrations of BALB/c mice and NZB/W F1 male mice were 1.88 (SD 0.13) $\mathrm{mmol} / 1$ and 3.60 (SD 0.27 ) $\mathrm{mmol} / \mathrm{l}$ respectively.

\section{Liver and serum fatty acid pattern and fat content of liver tissues}

The fat content of liver tissue is summarized in Table 2. There were no significant differences in hepatic triacylglycerol, cholesterol, phospholipid or total lipid concentrations between the low-fat diet group and the high-fat diet group. The liver and serum fatty acid composition patterns are summarized in Table 3 . The results showed that palmitic acid $(16: 0)$, palmitoleic acid $(16: 1 n-9)$ and oleic acid $(18: 1 n-9)$ contents were significantly 

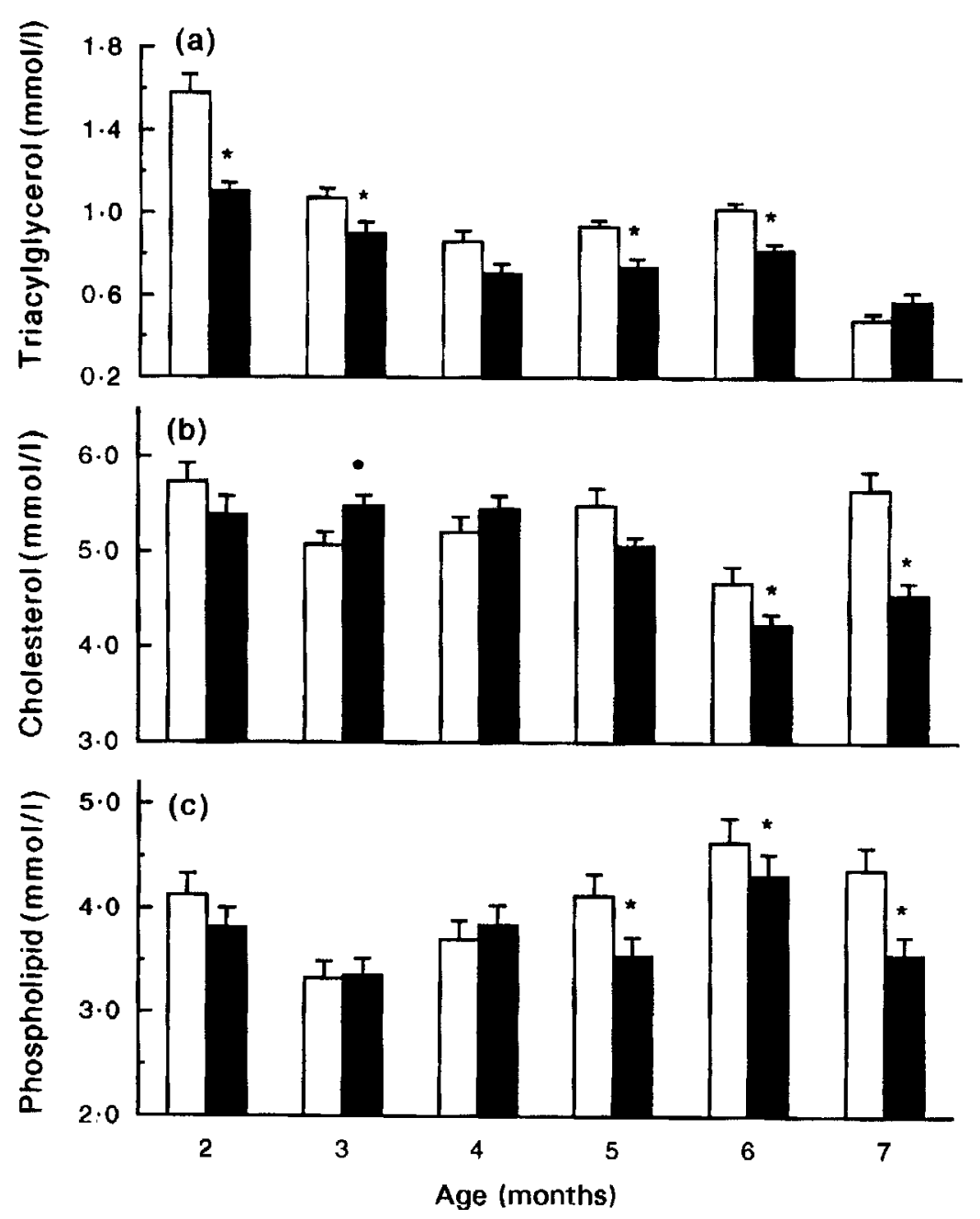

Fig. 1. (a) Serum triacylglycerol, (b) serum cholesterol and (c) serum phospholipid concentrations of NZB/W F1 female mice fed on diets containing $50(\square)$ or $200(\square) \mathrm{g}$ fat $/ \mathrm{kg}$. Values are means with their standard errors for examples from twelve mice. * Mean values were significantly different for those for the $50 \mathrm{~g}$ fat $/ \mathrm{kg}$ diet group $(P<0.05 ;$ Student's $t$ test).

higher in mice fed on $50 \mathrm{~g}$ fat $/ \mathrm{kg}$ diet compared with those of the $200 \mathrm{~g}$ fat $/ \mathrm{kg}$ diet group. In contrast, linoleic acid $(18: 2 n-6)$ and arachidonic acid $(20: 4 n-6)$ contents in the high-fat group were significantly higher than those in the low-fat diet group. The serum fatty acid patterns are also listed in Table 3. Because a limited amount of serum was available for analysis, sera from six mice of each group were pooled for this measurement. Although statistical analysis was not possible, serum fatty acid patterns for low-fat and high-fat groups were similar to their hepatic fatty acid patterns.

\section{Anti-cardiolipin and anti-single-stranded DNA antibodies}

Mice were bled retro-orbitally every month, and serum samples were collected for determination of anti-cardiolipin (Fig. 2) and anti-ssDNA antibodies (Fig. 3). In these two 
Table 2. Hepatic lipids of 7-month-old female NZB/W F1 mice fed on diets with different contents of fat*

(Mean values with their standard errors for six mice per dietary group)

\begin{tabular}{|c|c|c|c|c|c|c|c|c|}
\hline \multirow[b]{2}{*}{ Group } & \multicolumn{2}{|c|}{$\begin{array}{c}\text { Triacylglycerol } \\
\text { (mg/g liver) }\end{array}$} & \multicolumn{2}{|c|}{$\begin{array}{l}\text { Cholesterol } \\
\text { (mg/g liver) }\end{array}$} & \multicolumn{2}{|c|}{$\begin{array}{l}\text { Phospholipid } \\
\text { (mg/g liver) }\end{array}$} & \multicolumn{2}{|c|}{$\begin{array}{c}\text { Total lipid } \\
\text { (mg/g liver) }\end{array}$} \\
\hline & Mean & $\mathrm{SE}$ & Mean & $\mathrm{SE}$ & Mean & SE & Mean & SE \\
\hline $50 \mathrm{~g} \mathrm{fat} / \mathrm{kg}$ & 29.9 & 4.9 & 6.52 & 0.70 & 6.27 & 0.67 & 94.7 & 5.5 \\
\hline $200 \mathrm{~g} \mathrm{fat} / \mathrm{kg}$ & 37.6 & 4.7 & 6.52 & 0.85 & 7.26 & 0.42 & 142.7 & 40.2 \\
\hline Student's $t$ test & \multicolumn{2}{|c|}{$P=0.2859$} & \multicolumn{2}{|c|}{$P=0.9941$} & \multicolumn{2}{|c|}{$P=0.2425$} & \multicolumn{2}{|c|}{$P=0.2890$} \\
\hline
\end{tabular}

* Mice were fed for 5 months on a low-fat diet containing $50 \mathrm{~g}$ fat and $650 \mathrm{~g}$ carbohydrate/kg or a high-fat diet containing $200 \mathrm{~g}$ fat and $500 \mathrm{~g}$ carbohydrate $/ \mathrm{kg}$. For details of diets see Table 1 and p. 658 .

Table 3. The fatty acid pattern in serum and liver of 7-month-old female NZB/W F1 mice fed on diets with different contents of fat*

(Mean values with their standard errors for six mice per dietary group)

\begin{tabular}{|c|c|c|c|c|c|c|c|}
\hline \multirow{3}{*}{$\begin{array}{l}\text { Group ... } \\
\text { Fatty acid }\end{array}$} & \multicolumn{5}{|c|}{ Liver (mg/g liver) } & \multicolumn{2}{|c|}{ Serum $(\mathrm{mmol} / \mathrm{l})^{\dagger}$} \\
\hline & \multicolumn{2}{|c|}{$50 \mathrm{~g} \mathrm{fat} / \mathrm{kg}$} & \multicolumn{2}{|c|}{$200 \mathrm{~g}$ fat $/ \mathrm{kg}$} & \multirow{2}{*}{$\begin{array}{c}\text { Student's } \\
t \text { test }\end{array}$} & \multirow[t]{2}{*}{$50 \mathrm{~g}$ fat $/ \mathrm{kg}$} & \multirow[t]{2}{*}{$200 \mathrm{~g} \mathrm{fat} / \mathrm{kg}$} \\
\hline & Mean & SE & Mean & SE & & & \\
\hline $16: 0$ & 13.7 & $1 \cdot 2$ & 9.24 & 1.20 & $P=0.0252$ & $1 \cdot 33$ & 1.05 \\
\hline $16: 1 n-9$ & $5 \cdot 02$ & 0.42 & 1.56 & 0.25 & $P=0.0001$ & ND & ND \\
\hline $18: 0$ & 1.86 & 0.40 & 2.58 & 0.28 & $P=0.1750$ & $0 \cdot 81$ & 1.13 \\
\hline $18: 1 n-9$ & 35.6 & $3 \cdot 5$ & $11 \cdot 1$ & 1.4 & $P=0.0001$ & 0.99 & 0.64 \\
\hline $18: 2 n-6$ & 7.22 & 0.88 & 14.6 & $2 \cdot 22$ & $P=0.0117$ & 1.50 & 1.64 \\
\hline $20: 4 n-6$ & 1.05 & 0.18 & 4.08 & 1.07 & $P=0.0370$ & $0 \cdot 33$ & 0.53 \\
\hline
\end{tabular}

ND, not detectable.

* Mice were fed for 5 months on a low-fat diet containing $50 \mathrm{~g}$ fat and $650 \mathrm{~g}$ carbohydrate/kg or a high-fat diet containing $200 \mathrm{~g}$ fat and $500 \mathrm{~g}$ carbohydrate/kg. For details of diets see Table 1 and p. 658 .

† The values for serum fatty acid composition were obtained from a pooled serum sample from six mice.

groups, IgM anti-cardiolipin antibody increased gradually with age and no statistical significance was noted between these two groups (Fig. 1(b)). Interestingly, IgG anticardiolipin antibodies (Fig. 1(a)) in the high-fat group were significantly higher than in the low-fat diet group at the early age ( $P=0.0001$ at 3 months; $P=0.0146$ at 4 months) and remained at that level at the late age. IgG anti-ssDNA antibodies in these two groups increased from the age of 5 months (Fig. 2), with a higher value in the high-fat diet group, although not significantly $(P=0.0523$ at 6 months, $0.134<P<0.151$ at 4,5 and 7 months). Increased IgM anti-ssDNA antibody levels were noted at the early age and increased markedly at the age of 7 months.

\section{Serum immunoglobulin level}

To investigate whether the high-fat diet affected total serum Ig contents, serum IgG, IgM and IgA levels were measured. Values for serum IgG, IgM and IgA for 6-month-old mice are shown in Table 4 . The serum IgG concentration in the high-fat group was significantly higher than that of the low-fat diet group. The data shown here suggested that the serum IgM levels of these two groups were very similar. In contrast, the serum IgA concentration 

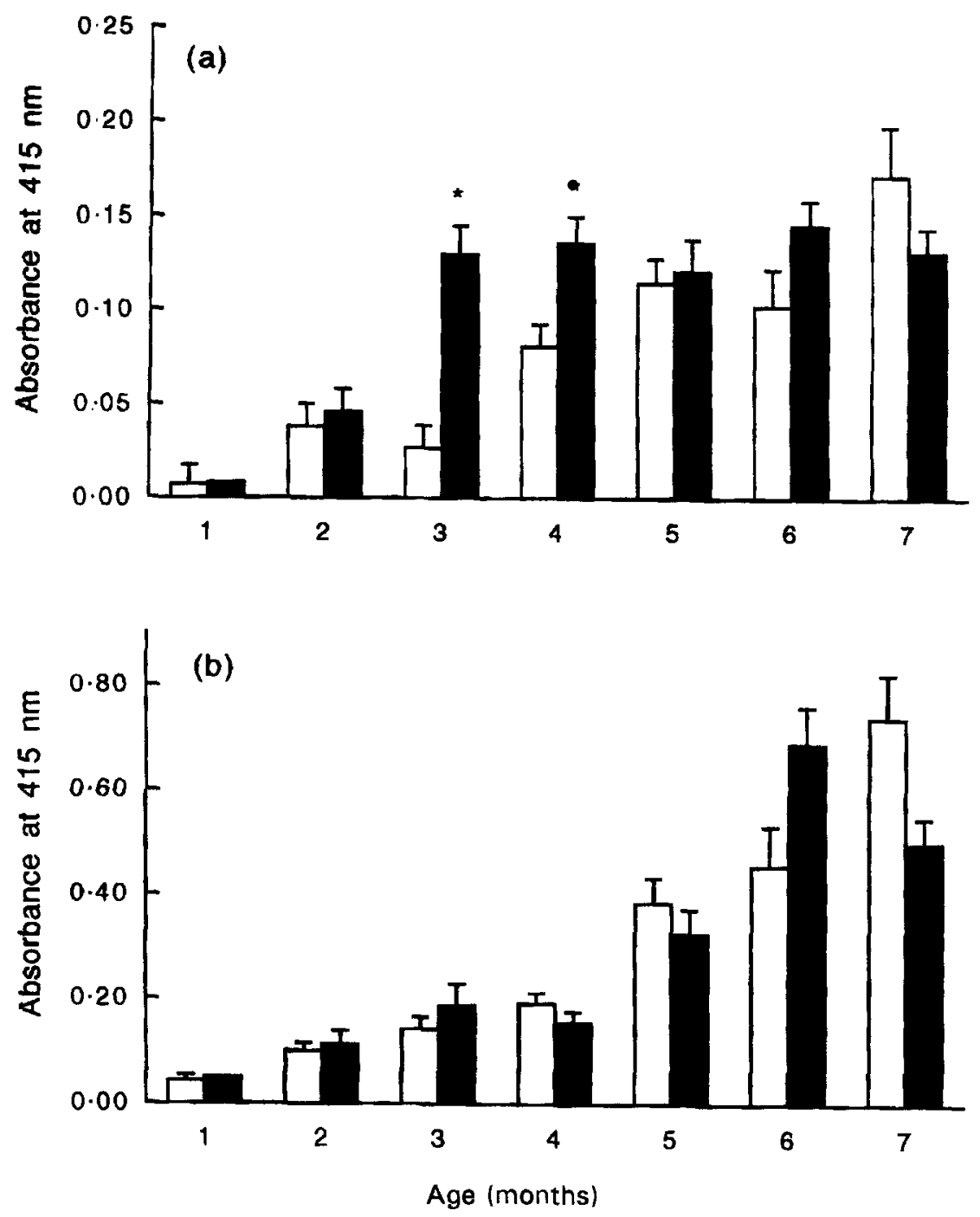

Fig. 2. (a) Serum anti-cardiolipin immunoglobulin $G$ (IgG) levels and (b) serum anti-cardiolipin immunoglobulin $M$ (IgM) levels of NZB/W F1 female mice fed on diets containing $50(\square)$ or $200(\square) \mathrm{g}$ fat $/ \mathrm{kg}$. IgG levels were from 50 fold and IgM levels from 100-fold dilution of each serum sample. Values are means with their standard errors for examples from twelve mice. * Mean values were significantly different from those for the $50 \mathrm{~g}$ fat $/ \mathrm{kg}$ diet groups $(P<0.05 ;$ Student's $t$ test $)$.

in mice of the high-fat diet group was lower than that in mice of the low-fat diet group $(P=0.0002)$.

\section{Mitogen responses}

Table 5 shows that spleen cells isolated from mice fed on either the low-fat diet or the highfat diet had a higher proliferative response to LPS than to Con A. The spleen cells of mice fed on the high-fat diet showed higher responses to either 5 or $10 \mu \mathrm{g} / \mathrm{ml}$ Con A stimulation compared with the low-fat diet group ( $P<0.05$ for $10 \mu \mathrm{g} / \mathrm{ml}$ Con A). The responses of 

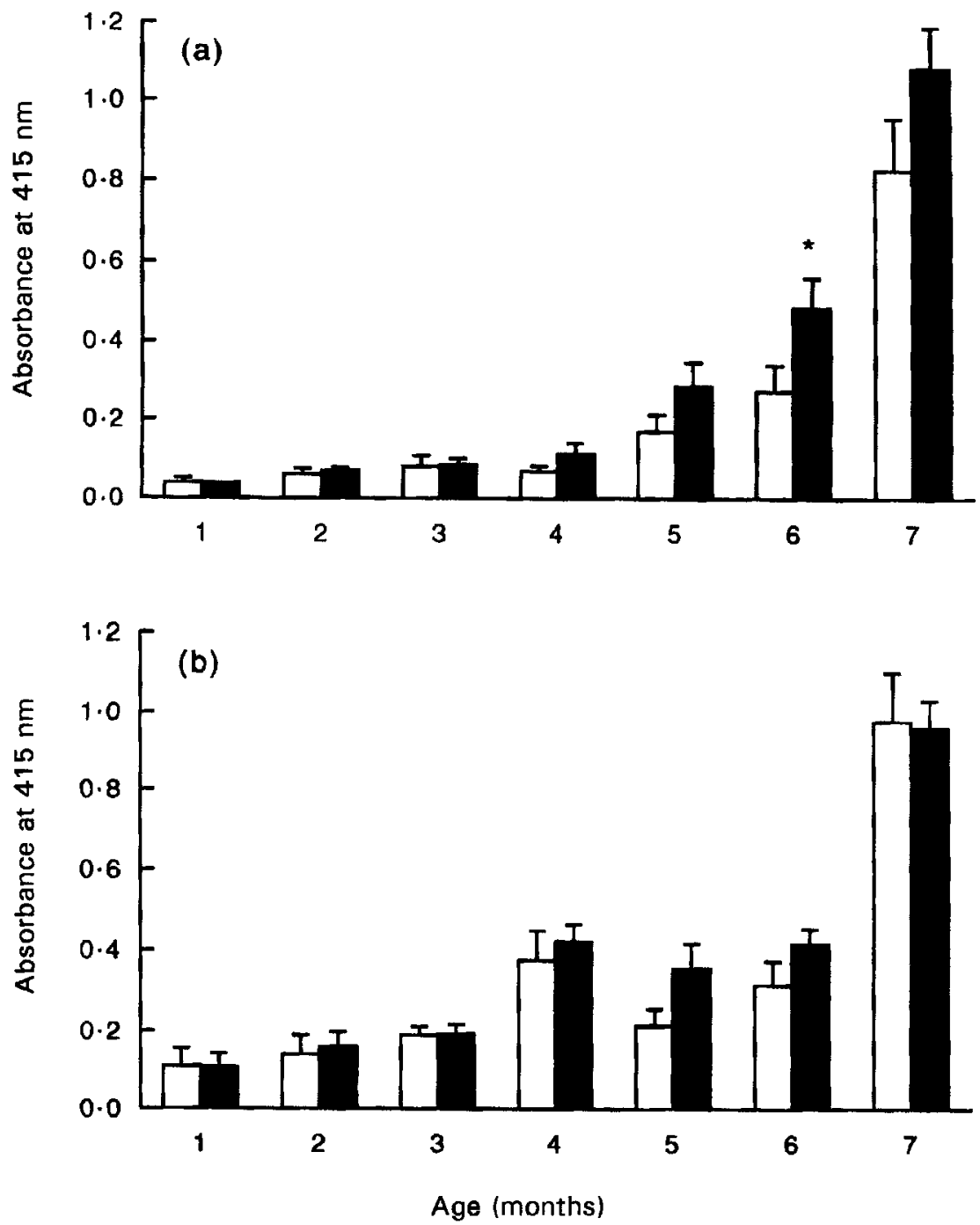

FIg. 3. (a) Serum anti-single-stranded DNA immunoglobulin $G$ levels and (b) serum anti-single-stranded DNA immunoglobulin M levels of NZB/W F1 female mice fed on diets containing $50(\square)$ or $200(\square) \mathrm{g}$ fat $/ \mathrm{kg}$. Each serum sample was diluted 400 -fold. Values are means with their standard errors for examples from twelve mice. $\left({ }^{*} P=0.0523\right.$, NS, Student's $t$ test).

spleen cells to $5 \mu \mathrm{g} / \mathrm{ml}$ LPS were higher in the high-fat diet group but this difference was not significant $(P=0 \cdot 1698)$. The proliferative response to $25 \mu \mathrm{g} / \mathrm{ml}$ LPS was very similar between the two groups.

\section{DISCUSSION}

It is noteworthy that dietary fat affected serum lipid contents but not hepatic lipid contents in autoimmune-prone NZB/W F1 mice. The mice fed on $200 \mathrm{~g}$ fat $/ \mathrm{kg}$ diet had significantly lower levels of serum triacylglycerol. The serum cholesterol levels of mice fed on the highfat diet were significantly higher at the age of 3 months but lower at the age of 6-7 months 
Table 4. Serum immunoglobulin (Ig)G, IgM and IgA concentrations ( $\mathrm{mg} / \mathrm{ml}$ ) in 6-month-old female NZB/W F1 mice fed on diets with different contents of fat*

(Mean values with their standard errors for twelve mice per dietary group)

\begin{tabular}{|c|c|c|c|c|c|c|}
\hline \multirow[b]{2}{*}{ Group } & \multicolumn{2}{|c|}{$\operatorname{Ig} G$} & \multicolumn{2}{|c|}{ IgM } & \multicolumn{2}{|c|}{$\operatorname{IgA}$} \\
\hline & Mean & $\mathrm{SE}$ & Mean & SE & Mean & SE \\
\hline $50 \mathrm{~g}$ fat $/ \mathrm{kg}$ & 7.86 & 0.76 & 0.80 & 0.03 & 0.64 & 0.03 \\
\hline $200 \mathrm{~g}$ fat $/ \mathrm{kg}$ & $10 \cdot 26$ & 0.53 & 0.79 & 0.02 & 0.48 & 0.02 \\
\hline Student's $t$ test & \multicolumn{2}{|c|}{$P=0.0165$} & \multicolumn{2}{|c|}{$P=0.8956$} & \multicolumn{2}{|c|}{$P=0.0002$} \\
\hline
\end{tabular}

* Mice were fed for 5 months on a low-fat diet containing $50 \mathrm{~g}$ fat and $650 \mathrm{~g}$ carbohydrate/kg or a high-fat diet containing $200 \mathrm{~g}$ fat and $500 \mathrm{~g}$ carbohydrate $/ \mathrm{kg}$. For details of diets see Table 1 and p. 658 .

Table 5. Mitogenic response of 7-month-old female NZB/W F1 mice fed on diets with different contents of fat*

(Mean values with their standard errors for six mice per dietary group)

\begin{tabular}{|c|c|c|c|c|c|c|c|c|}
\hline \multirow[b]{3}{*}{ Group } & \multicolumn{8}{|c|}{ Stimulation index } \\
\hline & \multicolumn{2}{|c|}{ ConA 5} & \multicolumn{2}{|c|}{ ConA 10} & \multicolumn{2}{|c|}{ LPS 5} & \multicolumn{2}{|c|}{ LPS 25} \\
\hline & Mean & SE & Mean & SE & Mean & SE & Mean & $S E$ \\
\hline $50 \mathrm{~g} \mathrm{fat} / \mathrm{kg}$ & $4 \cdot 3$ & $3 \cdot 3$ & $10 \cdot 0$ & $3 \cdot 1$ & 44.8 & $9 \cdot 1$ & $15 \cdot 9$ & $7 \cdot 1$ \\
\hline $200 \mathrm{~g} \mathrm{fat} / \mathrm{kg}$ & 11.8 & $5 \cdot 1$ & 25.6 & 4.5 & $72 \cdot 8$ & 16.6 & $16 \cdot 0$ & $5 \cdot 8$ \\
\hline Student's $t$ test & \multicolumn{2}{|c|}{$P=0.2916$} & \multicolumn{2}{|c|}{$P=0.0217$} & \multicolumn{2}{|c|}{$P=0.1698$} & \multicolumn{2}{|c|}{$P=0.9934$} \\
\hline
\end{tabular}

ConA, concanavalin A; LPS, lipopolysaccharide.

* Mice were fed for 5 months on a low-fat diet containing $50 \mathrm{~g}$ fat and $650 \mathrm{~g}$ carbohydrate/kg or a high-fat diet containing $200 \mathrm{~g}$ fat and $500 \mathrm{~g}$ carbohydrate/kg. For details of diets see Table 1 and $\mathrm{p}$. 658 . Spleen cells were incubated with medium only or in the presence of Con A at a final concentration of 5 or $10 \mu \mathrm{g} / \mathrm{ml}$ or LPS at a final concentration of 5 or $25 \mu \mathrm{g} / \mathrm{ml}$ for $72 \mathrm{~h}$.

when disease developed. The serum phospholipid levels were also significantly lower in the high-fat diet group at the later age. One study reported that increased serum triacylglycerol levels were found in lupus patients who had been treated with $10 \mathrm{mg}$ prednisolone/d (MacGregor et al. 1992). These lines of evidence suggest that a low triacylglycerol level and higher autoantibody levels may be closely related to the severity of disease in human and murine lupus. Dietary fat intake, as well as steroid treatment, might affect lipid metabolism in SLE patients although the relationship between lipid contents and autoantibody levels is not clear.

Our data showed that a high-fat diet increased hepatic linoleic acid $(18: 2 n-6)$ and arachidonic acid $(20: 4 n-6)$ contents in autoimmune-prone NZB/W F1 mice. It has also been reported that NZB/W F1 mice fed on a diet containing $200 \mathrm{~g}$ safflowerseed oil $/ \mathrm{kg}$ (high in 18:2n-6 fatty acid) showed earlier and higher anti-DNA antibody responses and shorter life spans compared with those fed on a $200 \mathrm{~g}$ coconut oil $/ \mathrm{kg}$ diet (Hurd et al. 1981). Mice fed on $250 \mathrm{~g}$ beef tallow $/ \mathrm{kg}$ diet were reported to have significantly higher serum $18: 2 n-6$ and $20: 4 n-6$ fatty acid contents and shorter life spans compared with mice fed on menhaden oil (Prickett et al. 1981). The data do not simply reflect the fatty acid composition of the diet because certain fatty acids such as $16: 1 n-9$ and $18: 1 n-9$ were higher in mice fed with only $50 \mathrm{~g}$ dietary fat $/ \mathrm{kg}$. In the present study, the serum fatty acid composition could not be analysed statistically due to the limited amount of sample 
available. Nevertheless, the serum fatty acid profile between the two dietary fat groups was noted to be similar to the hepatic fatty acid profile. Increases of hepatic $18: 2 n-6$ and $20: 4 n-6$ as seen in the high-fat diet group may affect lipid metabolism and prostaglandin production, which may subsequently affect the immune response, for example by inhibition of interleukin 2 production and macrophage Ia expression (Snyder et al. 1982; Santoli \& Zurier, 1989). A higher Con A-stimulated proliferative response of spleen cells was seen in mice fed on $200 \mathrm{~g}$ dietary fat $/ \mathrm{kg}$ than in those fed on $50 \mathrm{~g}$ fat $/ \mathrm{kg}$. These findings are different from previous reports by other groups (Levy et al. 1982; Morrow et al. 1985); however, the difference in the quantity (12 and $90 v .50$ and $200 \mathrm{~g} \mathrm{fat} / \mathrm{kg}$ diet) and quality of dietary fat used in these studies may have contributed to the different results.

Although the aetiology of SLE remains elusive, it has been suggested that constitutional, environmental and immunological factors are all involved (Steinberg $e t$ al. 1981; Theofilopoulos \& Dixon, 1981). Both human and murine forms of SLE exhibit a characteristic spectrum of autoantibodies such as anti-erythrocyte, anti-DNA and antiphospholipid antibodies (Theofilopoulos et al. 1989). Among these autoantibodies, IgG anti-double stranded DNA (anti-dsDNA) antibody is thought to be pathogenic and T-cell dependent (Datta et al. 1987; Carteron et al. 1989). Antibodies to phospholipid are a heterogeneous group of autoantibodies found in the serum of SLE patients or murine lupus. Anti-cardiolipin antibodies have been closely related to antiphospholipid syndrome which includes venous and arterial thrombosis. thrombocytopenia, and recurrent fetal loss (Harris et al. 1983; Koike et al. 1984; Lockshin et al. 1985; McNeil et al. 1991). Studies suggest that the level of $\mathrm{IgG}$ anti-cardiolipin antibodies is more closely related to the development of thrombosis and thrombocytopenia. In contrast, anti-cardiolipin antibody of the IgM isotype has been linked to haemolytic anaemia and livedo reticularis (Mackworth-Young, 1990).

Cross-reactivity of anti-cardiolipin antibodies with autoantigens such as negatively charged phospholipids and ssDNA has been well documented (Lafer et al. 1981). Pathogenic anti-DNA and anti-cardiolipin antibodies in both murine and human lupus are of the IgG isotype (Datta et al. 1987). In the present study, both IgG anti-ssDNA and anticardiolipin antibody titres increased with age. In NZB/W F1 mice, isotype switch of antiss, dsDNA antibodies has been well documented which suggests an antigen-driven process in the development of anti-DNA antibodies. A similar finding in the present study was noted in the serum level of anti-cardiolipin antibody, suggesting antigen involvement in this process. Because of obvious cross-reactivity between anti-cardiolipin antibody and anti-ssDNA antibody, both autoantibodies might be a result of response to a similar foreign antigen (Shoenfeld et al. 1983; Carroll et al. 1985). In the present study, IgG anticardiolipin antibodies in the high-fat diet group were higher than those in the low-fat group at the early age and IgG anti-ssDNA antibodies showed a higher value in the high-fat diet group at that time. Our previous study showed increased IgG anti-dsDNA antibody level in mice fed on high dietary fat (Lin et al. 1996). However, further investigation of crossreactivity between anti-DNA antibodies and anti-cardiolipin antibodies is necessary to elucidate this problem.

The present study showed that the production of IgG anti-cardiolipin antibodies increased in mice fed on a high-fat diet at an earlier age than the level of IgG anti-DNA antibody. This suggested that a high-fat diet might play a critical role in increased abortion rate in SLE by increasing anti-cardiolipin antibody production. Our data also showed that high dietary fat increased 18:2 and 20:4 fatty acids in autoimmune-prone NZB/W F1 mice. However, more studies are needed to clarify the real mechanisms involved. 
The authors are grateful for the helpful advice and for technical assistance from Professor Min-Hsiung Lee in fatty acid composition analysis. This study was supported by a grant from the National Science Council of the Republic of China; NSC 83-0409-B-002-065.

\section{REFERENCES}

Berger, A., Gershwin, M. E. \& German, J. B. (1992). Effects of various dietary fats on cardiolipin acyl composition during ontogeny of mice. Lipids $27,605-612$.

Carlson, S. E. \& Goldfarb, S. (1979). A sensitive enzymatic method for the determination of free and esterified tissue cholesterol. Clinica Chimica Acta 79, 575-582.

Carroll, P., Stafford, D., Schwartz, R. S. \& Stollar, B. D. (1985). Murine monoclonal anti-DNA autoantibodies bind to endogenous bacteria. Journal of Immunology 135, 1086-1090.

Carteron, N. L., Schimenti, C. L. \& Wofsy, D. (1989). Treatment of murine lupus with $F\left(a^{\prime}\right) 2$ fragments of monoclonal antibody to L3T4. Suppression of autoimmunity does not depend on T helper cell depletion. Journal of Immunology 142, 1470-1475.

Datta, S. K., Patel, H. \& Berry, D. (1987). Induction of cationic shift in IgG anti-DNA autoantibodies. Role of T helper cells with classical and novel phenotypes in three murine models of lupus nephritis. Joumal of Experimental Medicine 165, 1252-1268.

Eilat, D., Zlotnick, A. Y. \& Fischel, R. (1986). Evaluation of the cross-reaction between anti-DNA and anticardiolipin antibodies in SLE and experimental animals. Clinical Experimental Immunology 65, 269-278.

Fernandes, G., Yunis, E. J. \& Good, R. A. (1976). Influence of diet on survival of mice. Proceedings of the National Academy of Sciences USA 73, 1279-1283.

Folch, J., Lees, M. \& Sloane-Stanley, G. (1957). A simple method for the isolation and purification of total lipids from animal tissues. Journal of Biological Chemistry 226, 497-509.

Fossati, P. \& Prencipe, L. (1982). Serum triglycerides determined colorimetrically with an enzyme that produces hydrogen peroxide. Clinical Chemistry 28, 2077-2080.

Gajjar, A., Kubo, C., Johnson, B. C. \& Good, R. A. (1987). Influence of extremes of protein and energy intake on survival of B/W mice. Journal of Nutrition 117, 1136-1140.

Haeeis, E. N., Gharavi, A. E., Patel, S. P. \& Hughes, G. R. V. (1987). Evaluation of the anticardiolipin antibody test: report of an international workshop held April 1986. Clinical Experimental Immunology 68, 212-215.

Harris, E. N., Gharavi, A. E., Boey, M. L., Patel, B. M., Mackworth-Young, C. G., Loizou, S. \& Hughes, G. R. V. (1983). Anticardiolipin antibodies: detection by radioimmunoassay and association with thrombosis in systemic lupus erythematosus. Lancet 2, 1211-1214.

Hashimoto, Y., Kawamura, M., Ichikawa, K., Suzuki, T., Sumida, T., Yoshida, S., Matsuura, E., Ikehara, S. \& Koike, T. (1992). Anticardiolipin antibodies in NEW $\times$ BXSB F1 mice: a model of antiphospholipid syndrome. Journal of Immunology 149, 1063-1068.

Hurd, E. T., Johnston, J. M, Okita, J. R., MacDonald, P. C., Ziff, M. \& Gilliam, J. N. (1981). Prevention of glomerulonephritis and prolonged survival in New Zealand Black/New Zealand White $F_{1}$ hybrid mice fed on essential fatty acid-deficient diet. Journal of Clinical Investigation 67, 476-483.

Koike, T., Sueishi, M., Funaki, H., Tomioka, H. \& Yoshida, S. (1984). Antiphospholipid antibodies and biological false positive serological test for syphilis in patients with systemic lupus erythematosus. Clinical Experimental Immunology 56, 193-199.

Koike, T., Tomioka, H. \& Kumagai, A. (1982). Antibodies cross-reactive with DNA and cardiolipin in patients with systemic lupus erythematosus. Clinical Experimental Immunology 50, 298.

Kubo, C., Johnson, B. C., Day, N. K. \& Good, R. A. (1984). Calorie source, calorie restriction, immunity and aging of (NZB/NZW) $F_{1}$ mice. Journal of Nutrition 114, $1884-1899$.

Lafer, E. M., Raugh, J., Andrzejewski, C. Jr, Mudd, D., Furie, B., Schwarz, R. S. \& Stollar, B. D. (1981). Polyspecific monoclonal lupus autoantibodies reactive with both polynucleotides and phospholipids. Journal of Experimental Medicine 153, 897-909.

Lee, M.-H., Wang, M.-L. \& Min, B.-W. (1990). Effects of methylation on determination of fatty acids. Food Science 17, 1-10.

Levy, J. A., Ibrahim, A. B., Shirai, T., Ohta, K., Nagasawa, R., Yoshida, H., Estes J. \& Gardner, M. (1982). Dietary fat affects immune response, production of antiviral factors, and immune complex disease in NZB/ NZW mice. Proceedings of the National Academy of Sciences USA 79, 1974-1978.

Lin, B.-F., Huang, C.-C., Chiang, B.-L. \& Jeng, S.-J. (1996). Dietary fat influences Ia antigen expression, cytokines and prostaglandin E2 production of immune cells in autoimmune-prone NZB $\times$ NZW F1 mice. British Journal of Nutrition 75, 711-722.

Lockshin, M. D., Druzin, M. L., Goei, S., Qamar, T., Magid, M. S., Janovic, L. \& Ferenc, M. (1985). Antibody to cardiolipin as a predictor of fetal distress or death in pregnant patients with systemic lupus erythematosus. New England Journal of Medicine 313, 152-156. 
MacGregor, A. J., Dhillon, V. B., Binder, A., Forte, C. A., Knight, B. C., Betterridge, D. J. \& Isenberg, D. A. (1992). Fasting lipids and anticardiolipin antibodies as risk factors for vascular disease in systemic lupus erythematosus. Annals of Rheumatic Diseases 51, 152-155.

Mackworth-Young, C. (1990). Antiphospholipid antibodies: more than just a disease marker? Immunology Today 11, 60-65.

McNeil, H. P., Chesterman, C. N. \& Krills, S. A. (1991). Immunology and clinical importance of antiphospholipid antibodies. Advances in Immunology 49, 193-280.

Morrow, W. J. W., Ohashi, Y., Hall, J., Pribnow, J., Hirose, S., Shirai, T. \& Levy, J. A. (1985). Dietary fat and immune function. I. Antibody response, lymphocyte and accessory cell function in (NZB $\times$ NZW) F1 mice. Journal of Immunology 135, 3857-3863.

National Research Council (1985). Guide for the Care and Use of Laboratory Animals. Publication no. 85-23 (revised). Bethesda, MD: National Institutes of Health.

Prickett, J. D., Robinson, D. R. \& Steinberg, A. D. (1981). Dietary enrichment with the polyunsaturated fatty acid eicosapentaenoic acid prevents proteinuria and prolongs survival in NZB/W F1 mice. Journal of Clinical Investigation 68, 556-559.

Rauch, J., Tannenbaum, H., Stollar, B. D. \& Schwartz, S. (1984). Monoclonal anti-cardiolipin antibodies bind to DNA. European Journal of Immunology 14, 529-534.

Richmond, N. (1973). Preparation and properties of a bacterial cholesterol oxidase from Nocardia sp. and its application to the enzymatic assay of total cholesterol in serum. Clinical Chemistry 19, 1350-1356.

Rupin, A., Gruel, Y., Watier, H., Girard, A. C., Leroy, J. \& Bardos, P. (1991). ELISA for the detection of anticardiolipin antibodies. High specificity based on the use of adult bovine serum as buffer and systematic subtraction of non-specific binding. Journal of Immunological Methods 138, 225-231.

Santoli, D. \& Zurier, R. B. (1989). Prostaglandin E precursor fatty acids inhibit human IL-2 production by a prostaglandin E-independent mechanism. Journal of Immunology 143, 1303-1309.

Shoenfeld, Y., Rauch, J., Massicotte, H., Datta, S. K., Andre-Schwartz, J., Stollar, B. D. \& Schwartz, R. S. (1983). Polyspecificity of monoclonal lupus autoantibodies produced by human-human hybridomas. New England Journal of Medicine 308, 414-420.

Snyder, D. S., Beller, D. I. \& Unanue, E. R. (1982). Prostaglandins modulate macrophage Ia expression. Nature 299, 163-165.

Steinberg, A. D., Huston, D. P., Taurog, J. D., Cowdery, J. S. \& Raveche, E. S. (1981). The cellular and genetic basis of murine lupus. Immunology Review 55, 121-154.

Takeyama, M., Itoh, S., Nayasaki, T. \& Tanimazu, I. (1977). A new enzymatic method for determinant of serum choline-containing phospholipids. Clinica Chimica Acta 79, 93-98.

Theofilopoulos, A. N. \& Dixon, F. J. (1981). Etiopathogenesis of murine SLE. Immunology Review 55, $179-216$.

Theofilopoulos, A. N., Kofler, R., Singer, P. A. \& Dixon, F. J. (1989). Molecular genetics of murine lupus models. Advances in Immunology 46, 61-109. 